\title{
Interlocking Factor Market in Agrarian Economy of Sri Lanka
}

\author{
Dr. S. M. Ahamed Lebbe \\ Department of Social Sciences \\ South Eastern University of Sri Lnka \\ Oluvil Park, Sri Lanka \\ E-mail address: smahamed08@gmail.com
}

Keywords: informal credit, interlinked credit transaction, rural sector, hidden costs

ABSTRACT. Informal credit market plays a crucial role in the rural sector in developing countries. Prices of goods and services, in general, in the competitive markets are determined by the market forces but, prices of factors of production in agrarian economy are interlinked, thus reward of land, labour and credit also are determined by the interlockers.. An interlinked transaction is one in which the parties trade in at least two markets on the condition that the terms of all trade between them are jointly determined (Bell and Srinivasan, 1989). Agriculture sector is the foremost economic activity in Sri Lanka. Nearly 70 percent of total population living in rural areas depends completely or partially on agriculture sector. The main objective of the study is to examine the incidence of different types of linkages prevalent in the developed and backward villages among paddy farming households in Sammanthurai Divisional Secretariat area of Ampara district in Sri Lanka. This study is based on primary data and the data related to the year 2011-2012 (2011 Yala and 2011-2012 Maha). According to the results 95 per cent of the households in backward villages and 65 per cent of households in developed villages are involved in interlinked credit transactions, Hence, the result exhibits that interlinked credit transaction is higher in backward villages than that of developed villages. The results further reveal that Cash-to-Labour and Kind-to-Labour transactions in developed villages are allowed free of charge. Kind-Cash and Input-to-Output transactions are completely seen in the backward villages. Input-to-Output market link which is foremost in the backward villages and it is found to be exploitative to the paddy farmers.

\section{INTRODUCTION}

The various exchange systems in the rural factor markets in Less Developed Countries are explained by number of researchers. It has been extensively studied by development economists not only in Asia but also all over the world. Informal credit market plays a vital role in the rural sector in developing countries. The concept of interlinkage has probably been borrowed from anthropology, where the multi-standard nature of relationships in small face-to-face communities has often been emphasized. Such societies have been called multiplex, and multiplex relationships between the same economic agents in a poor agrarian community are often described as interlinked contracts encompassing several markets (Gill, 2004). The credit transaction in the rural markets is not similar to transactions in the other markets like the goods market (Lianto, 1989). Prices of goods and services, in general, in the competitive markets are determined by the market forces but, prices of factors of production in agrarian economy are interlinked, as such reward of land, labour and credit are determined by the interlockers. Interlinked credit transactions can broadly be classified into four categories, namely those involving linkage of land, labour, inputs and output of farm households (Sarap, 1991). An interlinked transaction is one in which the parties trade in at least two markets on the condition that the terms of all trade between them are jointly determined (Bell and Srinivasan, 1989).

In general, it is stated that two parties involving in the interlocked factor market are identified as weaker party and stronger or dominant party. Interlinking of transaction in different markets is also very effective way for the dominant party to avoid social or legal controls on charging higher prices in some markets and to select criteria for rationing scarce resources (like credit and land) 
when prices are inflexible or sluggish in adjustment (Bardhan, 1980). The main manifestation of this imperfection is that access to factors of production is far more difficult for the weaker parties than for others. Besides, inadequate information which is caused by short supply of these factors, which in turn, lead to a rationing of them, can result in the stronger party exploiting the weaker party in the process of exchanging goods and services. Thus, it has been generally recognized that agrarian markets are highly fragmented and different parties in a given sub-market may have unequal access to the other markets (Sarap, 1991).

Weaker party is always identified as peasant and poorer than stronger party. The dominant party would have a sufficient power at this market. Hence, this situation leads to exploit the weaker party. It has been argued that because of the imperfection in the land and credit markets where the landlord/ money-lender poses localized monopoly, interlinking of credit with tenancy transactions increases the power of the landlord which leads a greater exploitation of the tenant (Bardhan, 1983). In the rural sector quite often credit is paid or repaid in kind, quite often interest is not explicit but implicit in the terms of the transaction (Bardhan, 1983). Since the interest payments are implicit at the market, the rate of interests is higher than the normal market interest rate. As a result, poor borrowers happen to pay more than actual payments.

Interlinked transactions bring this type of market under the control of dominant party. Bardhan (1973), Basu (1983), have explained about the various kinds of control exercised by the money-lenders over landless borrowers which strengthen the segmented and personalized character of these markets. Interlinking of transactions in different markets is also an effective way for the dominant party to avoid social or legal controls on charging high prices in some markets and to select criteria for rationing scarce resources when prices are inflexible or sluggish in adjustment (Bardhan 1980).

All the above theoretical based concepts show the negative sight of the interlocked factor market in rural sector. However, a number of studies indicate the benefit of interlinked credit transactions is an efficient way to reduce the excessive cost of acquiring information between transistors in imperfect market. Economists have not failed to show the advantages of interlinked credit transaction among markets. Brawerman and Stiglitz (1982) pointed out that it is an efficient response to information asymmetry and uncertainty. Brawerman and Guasch (1984) stated that this transaction plays as a screening device in the selection of consumers. On the other hand, Bell and Sirnivasan (1989) said that interlinked transaction is a flexible market response in the growing commercialization. They further pointed out that this transaction can increase economic efficiency in certain context. The study of Lemeilleur at al, (2005) explained the interlinked transactions between rice millers and producers. According to them "the coupling with credit access (particularly if there is a zero interest rate) is an effective incentive to discipline producer efforts toward the optimum". Thus, this transaction between rice millers and producers would appear to be an effective contractual arrangement to reduce transaction costs and to counteract market failure.

A number of other empirical studies have also established the existence of interlinked contracts. Narayana Reddy (1992) conducted an analysis on interlinkages of credit with factor and product markets in Andhra Pradesh. The results reported that the interlinked credit transactions are less in the developed village, while such transactions are highly prevalent in the backward village. Though the developed village is situated in the highly commercialized Tenali area of Guntur district, the credit linkages with marketing are totally absent. Mohapatra (1994) studied on land, labour and credit market interlocking in Orissa and found the nature of lease contracts and the degree of exploitation of tenants under interlocking arrangements mainly depend on the relative economic status of 'lessers' and their 'lessees'. The difference between the lesser and the lessee in terms of economic status is more pronounced in the irrigated villages than in the unirrigated once. Swain (1999) observed in his study that interlinked transactions are more prevalent in irrigated villages than the non-irrigated village. The tenants, attached labourers and farm servants are subjects to exploitation as the interest rate charged either explicitly or implicitly is found to be exorbitant, Deb and Rajeev (2007) analyzed that with the improvement in agricultural production and productivity, small and marginal farmers in West Bengal are depending on a new 
class of lenders for their working capital. Moneylenders disbursed credit only against collateral with the motive of acquiring the mortgage rather than recovering the loan. The rate of interest charged by a money lender is comparatively higher as she or he preferred a default. Komicha (2007) a farm household survey conducted in two districts of south-eastern Ethiopia from September 2004 to January 2005 and emphasized that farm households borrowed from the informal credit sector at significantly higher interest rates, particularly for consumption purposes. The financial institutions rationed loans to rural borrowers because they lacked the conventional collateral. Lakhwinder (2008) study on Rural Finance and Farmers' Indebtedness attempted explaining the indebtedness situation of the farmers' using secondary data in the two Punjabs. According to the results more than 58 per cent of debt among the Pakistani Punjab farm households was towards the informal sources and 52 per cent of debt among Indian Punjab farm households in 2003 was from informal sources. Udry (1990) survey on Credit Markets in Northern Nigeria reported that information asymmetries between the borrowers and lenders were unimportant, and their institutional consequences, the use of collateral and interlinked contracts were absent. Aleem (1990) conducted a study on imperfect information, screening, and the cost of informal lending in Pakistan. The results revealed that lender's charges were equal to their average cost of lending but exceeded their marginal cost. The finding was consistent with the view that the informal credit market was characterized by excess capacity and monopolistic competition in the presence of imperfect information. This survey theatrically explained the non-institutional lenders' cost in rural credit markets in Pakistan.

Many theoretical and empirical studies have explained different types of linkages in the rural sector such as land and labour markets, land and input markets, land and output markets, labour and output markets, input and output markets. The credit linkages between poor borrowers and lenders may be in several forms, namely, cash-to-cash (Cash receipt of the loan by the borrower and cash repayment of loan and interest to the creditors), cash-to-kind (Cash receipt of the loan and kind repayment), cash-to-labour (Cash receipt of the loan and repayment in the form of labour services), kind-to-cash (kind receipt of the loan and cash repayment), input-to-cash (input receipt of the loan and cash repayment), and cash-to-output (Cash receipt of the loan and repayment in the form of output). However, all repayments also include interest with loan amount

Agriculture sector is the foremost economic activity in Sri Lanka. Nearly 70 percent of total population living in rural areas depends completely or partially on agriculture sector. The paddy crop in Sri Lanka contributes 15 per cent of agricultural output, which is the highest contribution made by any single agricultural commodity. Ampara district is one of the major paddy cultivating regions of Sri Lanka. It contributes around 20 per cent of the total paddy production of the Island. This district has 16 per cent of the total cultivable land in Sri Lanka (Planning Secretariat, Ampara, 2009). Sammanthurai is the hub of paddy cultivation area in the Ampara district and nearly 68 per cent of the population is involved in paddy cultivation. Two-thirds of the total land area is used for paddy cultivation, which is 23.8 per cent of the total agricultural lands of the district. It is necessary to note that every year more than 16,000 ha are brought under paddy cultivation in Sammanthurai area.

\section{Objectives of the Study}

The main objective of the study is to examine the incidence of different types of linkages prevalent in the developed and backward villages among paddy farming households in Sammanthurai Divisional Secretariat area of Ampara district in Sri Lanka.

\section{Method of Data Collection}

This study is based on primary data and the data related to the year 2011-2012 (2011 Yala and 2011-2012 Maha). The field survey was conducted in four villages of Sammanthurai DS area of Ampara district in Sri Lanka. Malwatta, Valathappity and Mallikaithivu are the backward villages selected from backward areas, while Sammanthurai town area (GSN,1,2 3) and Block "J" East are selected from developed villages in Sammanthurai DS division. Selected backward villages are 
situated $8-10$ kilometer far from Sammanthurai down. A random sample of 60 households was drawn from the developed villages and 60 households from the backward villages thus making a total of 120 sample households for the study. Paddy farmer households were classified into four groups according to the paddy operation such as attached labourers, small (less than two acres), medium (two to five acres) and large farmer household (more than five acres).

\section{Descriptive of the Study Area}

Sammanthurai is situated in Ampara district of Sri Lanka. It is $15 \mathrm{~km}$ away from Ampara town. Sammanthurai is the most densely populated of the rural places in Ampara district. According to the Census of 2001, the total population was 50,971 and it has increased to 70,734 in 2012. Further, two-fifths of the population of Sammanthurai is living in the town area, while the rest (three-fifths) is living in the village part of the place (Divisional Secretariat, Sammanthurai, 2008). Paddy is the principal crop of the village. Literacy is moderate and supporting public infrastructure is also good. More than two-thirds of the total households depend on agriculture. Two-thirds of the total land area is used for paddy cultivation, which is 23.8 per cent of the total agricultural lands of the district. Since Sammanthurai is one of the big divisions in the extent of paddy cultivation in Ampara district, it has two Agrarian Service Centres (ASC), namely, Sammanthurai ASC and Malwatta ASC which are functioning under the D.S division of Sammanthurai. These two centres look after all the development of paddy cultivation in the study area. Sammanthurai and Malwatta ASC divisions hold 5,437ha and 3,802ha, respectively. Thereby, every year more than 16,000 ha are brought under paddy cultivation in both the ASC divisions of the study area.

Sammanthurai records an average temperature of $27^{\circ} \mathrm{C}$ to $30^{\circ} \mathrm{C}$ in a year and receives an average rainfall of $1,500 \mathrm{~m} . \mathrm{m}-2,225 \mathrm{~m} . \mathrm{m}$ per year. There is widespread use of attached labourers among the medium and large farm employers. The employers provide particular areas of their paddy lands to the attached labourers for cultivation. This contract is only for a period of a paddy cultivation season. It is a common practice in the study area that working period of the attached labourers mostly depends on personalized connection with the podiyar (Podiyar is a landlord or large farmer under whom the attached or the permanent labourers do work) However, the efficiency in paddy cultivation and other activities of labourers decide the working period of the labourers.

The rental system is also practised in the study area. Some big and medium landlords lease out their paddy lands for one or two seasons (for one year of cultivation) to the paddy farmers. The renting in paddy farmers (these are the farmers who take paddy lands for rent from others for cultivation) are most probably the landless labourers. Although the rent per acre per season is determined in the open market, in general, the personal connections (between the landlords and the leasing in paddy farmers) are the dominant factor in determining the rent for the land. The rent is often negotiated as well.

Despite banking facilities (or formal credit facilities) available in the area, the private moneylenders are very active. There are input traders who provide weedicides, pesticides and fertilizers to the farm households on the basis of credit. The rice millers and middlemen also provide financial help to the farmers for their paddy cultivation. Cash-to-output interlinked transactions between the farmers and the millers and the farmers and the middlemen are a normal practice in the study area. 

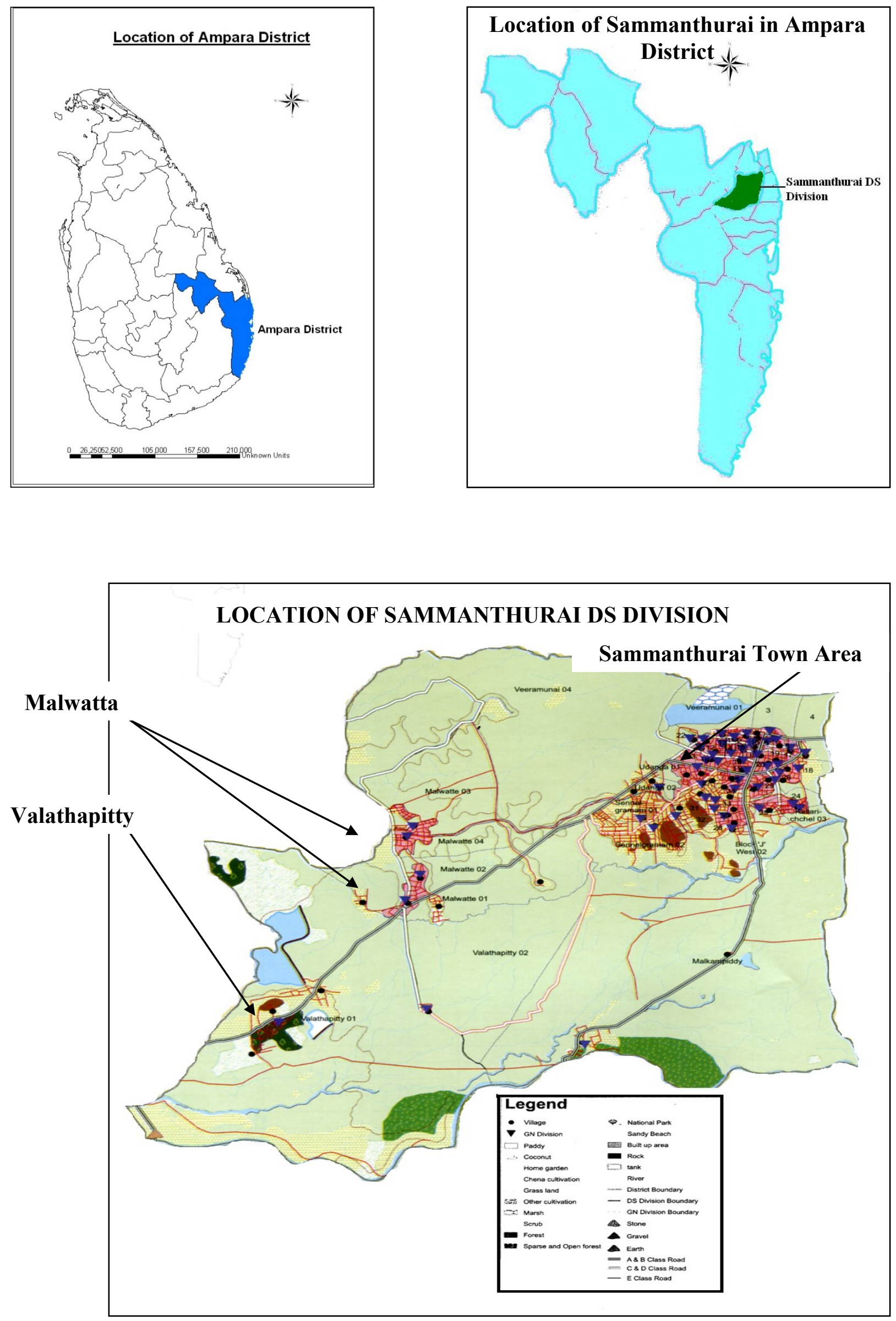


\section{CREDIT MARKET FACILITIES IN SAMMANTHURAI}

\section{Formal Sector}

The Sri Lankan government introduced an institutional credit scheme for paddy farmers from 1947 and the credit was made available through co-operative societies. This government funded credit scheme was replaced in September 1967 by the new agricultural credit scheme, under which provision of agricultural credit was made the responsibility of the banking system. The governmentowned People's Bank became the major commercial bank involved in this credit scheme. The Central Bank of Sri Lanka introduced a scheme to refinance agricultural credit granted by the commercial banks distributed through the co-operative rural banks and co-operative societies. With the other government-owned commercial bank, the Bank of Ceylon joining the scheme, it came to be known as the Comprehensive Rural Credit Scheme since 1973 (Wickramanayake, 2004).

Inspite of the various formal credit facilities extended by the Sri Lankan government, farmers still go to informal financial sector for their urgent and timely financial needs. Because, it is possible that credit can be received within short period and there is no constraint in regard to purpose of loan in the informal financial sector. Informal markets, in a poor agrarian economy, are usually highly fragmented and the different participants in a given sub-market may have unequal access to other markets (Subbrao, 1989). The credit transaction in the rural markets is not similar to transactions in the other markets like the goods market (Lianto, 1989).

The State and private bank facilities are made available formally to a certain extent in Sammanthurai. State branches such as People's Bank, Bank of Ceylon, National Saving Bank, Uva Development Bank and Co-operative Rural Development Bank are seen in Sammanthurai while private bank branches comprising of only Seylan and Hatton National Bank (HNB). However, it is to be noted that these facilities are available only in the town of Sammanthurai and not in the backward areas.

\section{Informal Sector}

Informal credit markets, in general, provide credit amenities to the poor people in city or rural area. The informal credit market of Sammanthurai Divisional Secretariat area is characterized by a diverse set of lenders such as traditional money lenders, traders, relatives and friends, Middlemen and millers and Podiyar.

Money lenders includes some people who have some amount of money but do not like to invest it on any self- employment ventures because of perceived risks and the fear of losing the money in bad investments. Moneylenders deal with their job only through the brokers.

The traders are in the habit of giving advance inputs (such as pesticides, weedicides and fertilizers) on credit to the borrowers on condition that they should refund it soon after the harvesting. The borrowers also agree to pay more than the actual amount borrowed. This is called Input-to-Cash transaction (I-C). Besides, there is another class of traders, namely, retail traders who sell consumer goods, who also give consumer goods on credit to their customers on the condition that they should return it as soon as they received the money. This is called Kind-to Cash (K-C) transaction.

Relatives and friends are the people who help their relatives and friends to assist their imperative needs. Low or higher amount and short term loans, in general, are given at zero interest rates in the study area. Middlemen and millers lend money to their customers on the condition that the loan received should be paid back in kind; that is, in the form of paddy as soon as the harvesting is over. Podiyar who is a employers under whom permanent labourers are engaged to work in the paddy fields, seasonally or habitually. If and when these attached labourers needed loan for home needs, consumption or any other urgent purposes. Podiyar give credit in cash or kind to them. But, the loans given to them have to be repaid or adjusted mostly by way of deducting it from his/her wages, earned in the form of paddy immediately after the harvesting. 


\section{RESULTS AND DISCUSSIONS}

The share of respondent household with interlinked and non-interlinked credit transactions in the informal credit market of study area are shown in table 1. The results exhibit that all farmers except medium farmers have involved more than 90 per cent in interlinked credit transactions in backward villages. Medium farmers' involvement is around 87 per cent. In contrary, Involvement of labourers and large farmers in interlinked credit transaction in Developed villages are 87 and 73 per cent, respectively. However, small and medium farmers engaged 47 and 53 per cent, respectively in developed villages.

In sum, 95 per cent of the households in backward villages involved in interlinked credit transactions. In terms of developed villages it is 65 per cent. Thus the non-interlinked transaction is around 05 per cent and 35 per cent in backward and developed villages, respectively. Hence, the result exhibits that interlinked credit transaction is higher in backward villages than that of developed villages.

Table 1. Extent of Interlinked and Non-Interlinked Credit Transactions in Backward and Developed Villages in Sammanthurai DS. Area

\begin{tabular}{|c|c|c|c|}
\hline $\begin{array}{l}\text { Paddy Farmers } \\
\text { Household Categories }\end{array}$ & $\begin{array}{l}\text { Number of Sample } \\
\text { Household }\end{array}$ & $\begin{array}{c}\text { Number of interlocked } \\
\text { Household }\end{array}$ & $\begin{array}{c}\text { Number of Non-interlocked } \\
\text { Household }\end{array}$ \\
\hline$(1)$ & $(2)$ & (3) & $(4)$ \\
\hline \multicolumn{4}{|c|}{ Backward Villages } \\
\hline Labourer & 15 & $\begin{array}{c}14 \\
(93.33)\end{array}$ & $\begin{array}{c}01 \\
(06.66)\end{array}$ \\
\hline Small & 15 & $\begin{array}{c}15 \\
(100.00)\end{array}$ & - \\
\hline Medium & 15 & $\begin{array}{c}13 \\
(86.66)\end{array}$ & $\begin{array}{c}02 \\
(13.33)\end{array}$ \\
\hline Large & 15 & $\begin{array}{c}15 \\
(100.00)\end{array}$ & - \\
\hline Total & $\begin{array}{c}60 \\
(100)\end{array}$ & $\begin{array}{c}57 \\
(95.00)\end{array}$ & $\begin{array}{c}03 \\
(05.00)\end{array}$ \\
\hline \multicolumn{4}{|c|}{ Developed Villages } \\
\hline Labourer & 15 & $\begin{array}{c}13 \\
(86.66)\end{array}$ & $\begin{array}{c}02 \\
(13.33)\end{array}$ \\
\hline Small & 15 & $\begin{array}{c}07 \\
(46.67)\end{array}$ & $\begin{array}{c}08 \\
(53.33)\end{array}$ \\
\hline Medium & 15 & $\begin{array}{c}08 \\
(53.33)\end{array}$ & $\begin{array}{c}07 \\
(46.67)\end{array}$ \\
\hline Large & 15 & $\begin{array}{c}11 \\
(73.33)\end{array}$ & $\begin{array}{c}04 \\
(26.67)\end{array}$ \\
\hline Total & $\begin{array}{c}60 \\
(100)\end{array}$ & $\begin{array}{c}39 \\
(65.00)\end{array}$ & $\begin{array}{c}21 \\
(35.00)\end{array}$ \\
\hline
\end{tabular}

Source: Computed from the primary data.

Note: Figures in the parenthesis denote percentage of Col. No.2.

The table 2 shows important types of interlinked credit transactions mainly linking with labour, inputs, and output markets in the study area. Cash- to- Cash transactions are the most important transactions in both developed and backward villages in the study area. This transaction contributes 39 per cent and 49 per cent in backward and developed villages, respectively. In the backward villages no cash- to- labour and kind- to- labour transactions as all farmers in these villages directly involve in paddy cultivation without employing attached labourers. However, large farmers only engage in this transaction. Although these transactions are shown in developed villages small farmers do not involve in these transactions. 
Table 2. Types of informal credit linkages in Developed and Backward Villages in Sammanthurai Divisional Secretariat Area

\begin{tabular}{|c|c|c|c|c|c|c|c|c|}
\hline $\begin{array}{l}\text { Paddy } \\
\text { Farmers } \\
\text { Household } \\
\text { Categories }\end{array}$ & $\begin{array}{l}\text { Number of } \\
\text { interlocked } \\
\text { Household }\end{array}$ & $\mathrm{C}-\mathrm{C}$ & C-L & K-L & K-C & I-C & I-O & C-O \\
\hline (1) & (2) & (3) & (4) & (5) & (6) & (7) & (8) & (9) \\
\hline \multicolumn{9}{|c|}{ Backward Villages } \\
\hline Labourer & 14 & $\begin{array}{c}06 \\
(42.85)\end{array}$ & - & - & $\begin{array}{c}09 \\
(64.28)\end{array}$ & - & - & $\begin{array}{c}01 \\
(07.14)\end{array}$ \\
\hline Small & 15 & $\begin{array}{c}05 \\
(33.33)\end{array}$ & - & - & $\begin{array}{c}06 \\
(40.00)\end{array}$ & $\begin{array}{c}08 \\
(53.33)\end{array}$ & $\begin{array}{c}06 \\
(40.00)\end{array}$ & $\begin{array}{c}04 \\
(26.67)\end{array}$ \\
\hline Medium & 13 & $\begin{array}{c}06 \\
(46.15)\end{array}$ & - & - & $\begin{array}{c}04 \\
(30.76)\end{array}$ & $\begin{array}{c}07 \\
(53.84)\end{array}$ & $\begin{array}{c}05 \\
(38.46)\end{array}$ & $\begin{array}{c}04 \\
(30.76)\end{array}$ \\
\hline Large & 15 & $\begin{array}{c}04 \\
(26.67)\end{array}$ & $\begin{array}{c}05 \\
(33.33)\end{array}$ & $\begin{array}{c}05 \\
(33.33) \\
\end{array}$ & $\begin{array}{c}03 \\
(20.00)\end{array}$ & $\begin{array}{c}07 \\
(46.67)\end{array}$ & $\begin{array}{c}07 \\
(46.67)\end{array}$ & $\begin{array}{c}09 \\
(60.00)\end{array}$ \\
\hline Total & $\begin{array}{c}57 \\
(100.00) \\
\end{array}$ & $\begin{array}{c}22 \\
(38.59) \\
\end{array}$ & $\begin{array}{c}05 \\
(08.77) \\
\end{array}$ & $\begin{array}{c}05 \\
(08.77) \\
\end{array}$ & $\begin{array}{c}21 \\
(36.84) \\
\end{array}$ & $\begin{array}{c}24 \\
(42.10)\end{array}$ & $\begin{array}{c}20 \\
(35.08)\end{array}$ & $\begin{array}{c}18 \\
(31.57) \\
\end{array}$ \\
\hline \multicolumn{9}{|c|}{ Developed Villages } \\
\hline Labourer & 13 & $\begin{array}{c}04 \\
(30.76)\end{array}$ & $\begin{array}{c}08 \\
(61.53)\end{array}$ & $\begin{array}{c}02 \\
(15.38)\end{array}$ & - & - & - & $\begin{array}{c}01 \\
(07.69)\end{array}$ \\
\hline Small & 07 & $\begin{array}{c}04 \\
(57.14) \\
\end{array}$ & - & - & - & $\begin{array}{c}02 \\
(28.57) \\
\end{array}$ & - & $\begin{array}{c}03 \\
(42.85) \\
\end{array}$ \\
\hline Medium & 08 & $\begin{array}{c}05 \\
(62.50)\end{array}$ & $\begin{array}{c}02 \\
(25.00)\end{array}$ & $\begin{array}{c}02 \\
(25.00)\end{array}$ & - & $\begin{array}{c}04 \\
(50.00)\end{array}$ & - & $\begin{array}{c}04 \\
(50.00) \\
\end{array}$ \\
\hline Large & 11 & $\begin{array}{c}06 \\
(54.54) \\
\end{array}$ & $\begin{array}{c}06 \\
(54.54) \\
\end{array}$ & $\begin{array}{c}03 \\
(27.27) \\
\end{array}$ & - & $\begin{array}{c}06 \\
(54.54) \\
\end{array}$ & - & $\begin{array}{c}05 \\
(45.45) \\
\end{array}$ \\
\hline Total & $\begin{array}{c}39 \\
(100.00\end{array}$ & $\begin{array}{c}19 \\
(48.71)\end{array}$ & $\begin{array}{c}16 \\
(41.02)\end{array}$ & $\begin{array}{c}07 \\
(17.94)\end{array}$ & - & $\begin{array}{c}12 \\
(30.76)\end{array}$ & - & $\begin{array}{c}15 \\
(38.46) \\
\end{array}$ \\
\hline
\end{tabular}

Source: Computed from the primary data.

Note: 1.This table refers to different types of interlinked credit transactions. Since some households entered into more than one interlinked credit transactions, the total number of interlinked transactions is larger than the total number of interlocked households.

2.Figures in the parenthesis denote percentage of Col. No.2.

The survey results further show that $\mathrm{C}-\mathrm{L}$ and $\mathrm{K}-\mathrm{L}$ transactions in developed villages are allowed free of charge. According to Rudhra and Bardhan (1983), fully attached labourers, taking consumption loan from the employer, is quite common and most of the loans in West Bengal are interest free. The loan advanced by the landlord or Podiyar to the attached labourers during the period of cultivation is repaid through reduction of wages of the attached labourers during the harvest period. In general, the landlord or the Podiyar of the study area does not collect any interest for this loan. In contrast, some landlords do not even recover the credit given by them to their labourers. The phenomenon of interest free loans has been encountered in the study region as well. But these have been loans advanced by the landlords to the attached labourers, at the time of attachment (Sarap, 1991). Therefore, the empirical studies have supported the results of the survey reported here.

$\mathrm{K}-\mathrm{C}$ (K include only consumption goods from retail good sellers) transaction is completely seen in backward villages. All categories of paddy farmers in backward villages involve $\mathrm{K}-\mathrm{C}$ transaction and it is inverse relationship with landholding in backward villages. As such K-C transaction is shown among incredibly poor famers. Further, the result exhibits that farmers in backward villages are poorer than developed villages. But, I-C transaction is shown in both villages. However, involvement of this transaction is higher in backward villages than that of developed villages. Despite the fact that I-O transaction (35\%) is shown only in backward villages. It is not in practice in developed villages.

Farmers in both villages engage in $\mathrm{C}-\mathrm{O}$ transaction. Poor farmers and labourers get loans from the middleman and the rice millers for their urgent needs during the cultivation period in the study area. These loans also are settled right soon after harvesting paddy. In general, due to excess of paddy supply, at the harvesting period the paddy price is lower than during the other period. 
Refunding takes place after the harvest, but it is the rice millers who choose the refunding day. He will demand paddy in the day when the market prices are lowest and can also benefit from the producer's lack of access to price details to set a price even lower than the market price (Lemelleur, 2005). The rice millers and middleman purchase paddy at the cheapest price from the poor farmers, in return for their loans without considering the current market price. Therefore, paddy farmers are exploited by C-O transaction and they indirectly pay higher interest rate for their loan. But this transaction little bit higher in developed villages when compare to backward villages in Sammanthurai Divisional Secretariat area.

\section{CONCLUSION AND POLICY RECOMMENDATIONS}

In this study an attempt has been made to find out the incidence of different types of linkages prevalent in the developed and backward villages among paddy farming households in Sammanthurai DS area of Ampara district in Sri Lanka. The analysis shows that the interlinked credit transactions are less in the developed villages, while such transactions are highly rampant in the backward villages. As such poor paddy farmers in the study area seek loan from informal credit sectors and disburse indirectly usury interest rate. K-C and I-O transactions are completely seen in the backward villages. I-O market link which is dominant in the backward villages and it is found to be exploitative to the weaker parties due to the hidden costs collected by the monopolist traders by over-valuing the prices of agricultural inputs supplied for the paddy and under-pricing the paddy output purchased by them. Credit linkages with input and output have been observed to exercise greater exploitation in the backward villages (Reddy M. Narayana, 1992). Therefore, poor paddy farmers are exploited by creditors in backward villages than in developed villages. It is obvious that the interlocked paddy farmers in both villages depend on creditors such as the traders, middlemen and mill owners, podiyars, owners of tractors and relatives and friends who have lent them money.

Keeping in view the result of this study, the following suggestions are extended for the consideration of planners and policy makers.

There should be an easy and enhanced access of paddy farmers to institutional credit facilities. The existing state and private bank branches are situated in Sammanthurai town area. As the interlinked credit transactions and the informal credit market are larger in backward villages, policy makers should attention to set up more formal sector facilities in Sammanthurai, in general, and in the backward villages, in particular.

The State and private banks have all been following the collateral system strictly for lending in Sri Lanka. This is not greatly appreciated by the poor paddy farmer households. Therefore, the collateral system is either done away with or reduced for the benefit of the poor farmers.

Farming households should be provided credit at minimum interest rate so that investment per acre can be increased which is necessary to enhance productivity and it leads to increase paddy farmers' income.

Policy initiatives should be taken to provide technical education for paddy farmers to use of different types of agricultural machinery at gross root level, which will enhance capability, and capacity of paddy farmers. 


\section{References}

[1] Aleem, I. (1990), "Imperfect Information, Screening, and the cost of Informal Lending: A study of a Rural Credit Market in Pakistan", World Bank Economic Review, Vol.4, No.3, pp.329349 .

[2] Bhaduri, A. (1973), “A Study in Agricultural Backwardness under Semi-Feudalism”, Economic Journal, Vol.83, No.1, pp.120-137.

[3] Bardhan, P.K. (1973), "On the Incidence of Poverty in Rural India in Sixties", Economic and Political Weekly, Vol.8, Nos. 4,5,6, 245-54.

[4] Bardhan, P.K. and Rudra, A. (1978), "Interlinkage of Land, Labour and Credit Relations: An Analysis of Village Survey Data in East India", Economic and Political Weekly, Vol.13, Annual Number, February.

[5] Bardhan, P.K. (1980), "Interlocking Factor Market and Agrarian Development: A Review of Issues”, Oxford Economic Papers, Vol. 35, No. 2, pp.262 -280

[6] Bardhan, P.K. (1984), "Land, Labour and Rural Poverty: Essays in Development Economics", Oxford University Press, Delhi.

[7] Bardhan, P. (1989), The Economic Theory of Agrarian Institutions, Oxford: GP: Clarendon Press.

[8] Basu, K. (1983), “The Emergence of Isolation and Interlinkage in Rural Market”, Oxford Economic Papers, Vol.35, No.2, pp.262 -280.

[9] Basu, K. (1984), "Implicit Interest Rates, Usury and Isolation in Backward Agriculture" Cambridge Journal of Economics, Vol. 8, No. 2, pp.145-159.

[10]Basu, K. (1984), The Less Developed Economy: A Critique of Contemporary Theory, Oxford University Press, New Delhi.

[11]Bell, C. and Srinivasan, T.N. (1989), "Interlinked Transactions in Rural Markets: An Empirical Study of Andhra Pradesh, Bihar and Punjab", Oxford Bulletin of Economics and Statistics, Vol.51, No.1, pp.73 -83.

[12]Braverman, A. and Gausch, J.L. (1984), “Capital Requirements, Screening and Interlinked Sharecropping and Credit Contracts," Journal of Development Economics, Vol. 14, pp.359-74.

[13]Braverman, A. and Stigliz, J.E. (1982), "Sharecropping and Interlinking of Agrarian Markets," American Economic Review, Vol. 73, No. 4, pp.693-715.

[14]Braverman, A. and Srinivasan, T.N. (1984), Agrarian Reform in Developing Rural Economics Characterized by Interlinked Credit and Tenancy Markets, in Binswanger and Rosenzweig.

[15]Deb, S. and Rajeev, M. (2007), "Banking on "Baniyas" for Credit", Economic and Political Weekly, January 27.

[16] Gill, Anita (2000), Rural Credit Markets, Financial Sector Reforms and The Informal Lenders, Deep and Deep Publications, New Delhi.

[17] Gil, Anita (2004), 'Interlinked Agrarian Credit Markets: Case Study Of Panjab', Economic and Political Weekly, Vol. 39, No.33, pp.3741-3751.

[18]Komicha, H. H. (2007), Farm Household Economic Behavior in Imperfect Financial Markets, Doctoral Thesis, Swedish University of Agricultural Sciences, Uppsala.

[19]Lakhwinder, S. (2008), "Rural Finance and Farmers' Indebtedness: A study of two Punjabs", MPRA Paper No 11195, Posted 20. Online http://mpra.ub.uni-muenchen, de/11195/ 
[20]Lemeilleur at al, (2005), 'Interlocking Transaction: Do they restrain the emergence of rice producer's organization in Cambodia? Paper presented at the ISNIE Conference, The Institutions of Market Exchange, Barcelona, MOI SA, 2, Place Viala. 34060 Montpellier Cedex 1, France.

[21]Lianto, M. (1989), “Asymmetries Information in Rural Financial Markets and Interlinking of Transactions Through Self Help Group", Journal of Philippine Development, Number 28, Vol. XVI, No. 1.

[22] Mohapatra, K. (1994), "Land, Labour and Credit Market Interlocking: A Study of Orissa Agriculture", Indian Journal of Agricultural Economics, Vol.49, No.3, pp.339-345.

[23] Narayana Reddy, M.V. (1992), "Interlinkages of Credit with Factor and Product Markets: A study in Andhra Pradesh", Indian Journal of Agricultural Economics, Vol.47, No.4, pp.618630.

[24] Sarap, K. (1990), "Interest Rate in Backward Agriculture: The Role of Economic and Extra Economic Control”, Cambridge Journal of Economics, Vol. 21, No. 2, pp.281-307.

[25] Sarap, K. (1991), Interlinked Agrarian Markets in Rural India, Sage Publication, New Delhi.

[26] Subbarao, (1989), Agricultural Marketing and Credit, Indian Council of Social Science Research, New Delhi.

[27] Swain, M. (1999), “Agricultural Tenancy and Interlinked Transactions: Neoclassical and Maxist Approaches”, Part I and Part II, Economic and Political Weekly, Vol. 34, No.37 \& 38, pp.2657-66 and 2752-2758

[28]Udry, C. (1990), "Credit Markets in Northern Nigeria: Credit as Insurance in a Rural Economy”, World Bank Economic Review, Vol.4. No-3, pp.251-269.

[29] Wickramanayake, J. (2004), "Financial Structure, Rural Credit and Supportive Institutional Frame Work in Sri Lanka: An empirical analysis", Department of Accounting and Finance, Monash University, Caulfield East, Victoria, Australia. 